\title{
Chronic pancreatitis is associated with a high prevalence of giardiasis
}

\author{
J Julian Lopez, MD, James A Wright, MD, Robert A Hammer, MD, Atilla ErTan, MD
}

JJ LOPEZ, JA WrIGHT, RA HAMMER, A ERTAN. Chronic pancreatitis is associated with a high prevalence of giardiasis. Can J Gastroenterol $1992 ; 6(2): 73-76$. In a previous study, a significantly higher prevalence of giardiasis was found in patients with cystic fibrosis compared with a control population $(28.0$ versus $6.3 \%, \mathrm{P}<0.0006)$. In this study, the prevalence of giardiasis in an adult population with chronic pancreatitis was investigated. The test population consisted of 15 patients with alcoholic pancreatitis and 50 volunteers with hypertension or orthopedic problems who were surveyed for Giardia lamblia by counterimmunoelectrophoresis (CIE) in fecal samples. CIE results were positive in four of 15 patients $(27 \%)$ with chronic pancreatitis and negative in all control subjects $(\mathrm{P}<0.001)$. It was concluded that patients with chronic pancreatitis, similar to patients with cystic fibrosis, have a previously unrecognized increased prevalence of giardiasis compared with a control population. It is important to investigate for $\mathrm{G}$ lamblia in any patient with pancreatic insufficiency whose diarrhea is difficult to control by dietary measures or pancreatic enzyme supplementation.

Key Words: Chronic pancreatitis, Diarrhea, Giardiasis

\section{La pancréatite chronique est associée à une prévalence élevée de giardiase}

RESUME: Une étude précédente notait une prévalence significativement plus élevée de giardiase parmi les patients porteurs de fibrose kystique que dans une population témoin $(28$ c. $6,3 \% \mathrm{P},<0,0006)$. Dans le présent article, les auteurs ont examiné la prévalence de giardiase dans une population de sujets adultes atteints de pancréatite chronique. La population étudiée comptait 15 patients souffrant d'une pancréatite alcoolique et 50 volontaires hypertendus ou présentant des problèmes orthopédiques. Les échantillons de fèces de tous les sujets ont été soumis à une contre-immunoélectrophorèse à la recherche de Giardia lamblia. On a relevé des résultats positifs chez quatre des quinze patients

Department of Medicine, Section of Gastroenterology, Tulane University Medical School, New Orleans, Louisiana, USA

Correspondence and reprints: Dr Atilla Ertan, Baylor College of Medicine, Suite 1122, Smith Tower, 6550 Fannin, Houston, TX 77030, USA. Telephone (713) 790-2171

Received for publication November 21, 1991. Accepted March 2, 1992
I IARDIA LAMBLIA IS A FLAGELlated enteric protozoan which has been contracted in every part of the world and is an important cause of endemic and epidemic diarrhea. The prevalence of $\mathrm{G}$ lamblia ranges from 1 to $20 \%$ and varies with socioeconomic level and age (1). In the United States, approximately $4 \%$ of the population harbour the organism, making it the most prevalent enteric parasite and the leading infectious agent identified in water-borne outbreaks of diarrhea. Between 1965 and 1984, 90 separate outbreaks affecting over 23,000 people were reported $(2,3)$.

Patients with symptomatic giardiasis often complain of acute or chronic diarrhea, weight loss and diffuse or epigastric abdominal pain (which often is exacerbated by eating and varying degrees of malabsorption symptoms) (4). These symptoms are similar to those frequently encountered in $\mathrm{pa}$ tients with chronic pancreatitis (5); although an association between these two diseases has been suspected (6), there has been no systematic investigation of a potential association. In a recent study, an increased prevalence of giardiasis was found in a group of patients with cystic fibrosis, all of whom had pancreatic exocrine insufficiency (7). Subsequently, the authors proceeded to investigate the preva- 
atteints de pancréatite chronique (27\%), et négatifs chez tous les sujets témoins $(\mathrm{P}<0,001)$. On conclut que l'augmentation de la prévalence de giardiase par rapport au groupe témoin n'était jusque-là pas reconnue chez les patients atteints de pancréatite chronique, comme chez les patients porteurs de fibrose kystique. Il est important de rechercher G lamblia chez tout insuffisant pancréatique dont les diarrhées restent rebelles à des mesures d'hygiène alimentaire ou à un apport complémentaire d'enzymes pancréatiques.

lence of giardiasis in an adult population with chronic pancreatitis and assess the effect of treatment on their symptoms.

\section{PATIENTS AND METHODS}

Fifteen patients (13 male, two female) aged 33 to 73 years (mean 50.4 ) suffering from alcohol-induced endstage chronic pancreatitis were selected. The diagnosis of chronic pancreatitis was established by results of plain radiographs of the abdomen, endoscopic retrograde cholangiopancreatography, computed tomog. raphy scan of the abdomen, secretin test and/or the Bentiromide test (Table 1). No patient was diagnosed as having chronic pancreatitis based only on the Bentiromide test.

All of the patients with chronic pancreatitis had steatorrhea and were receiving pancreatic enzyme supplementation. Nine of these patients had evidence of weight loss, diarrhea and postprandial abdominal pain for at least six months, and had failed to respond to conventional medical management for chronic pancreatitis. In these patients, the degree of weight loss ranged from 4.5 to $11 \mathrm{~kg}$ (mean net loss 7.4) and their diarrhea consisted of four to six bowel movements per day with production of foul-smelling stools. Sudan III stain demonstrated fat globules.

The control population consisted of 50 volunteers (42 male, eight female) aged 29 to 76 years (mean 48.9) from the same hospital population as the study group. They were being treated for uncomplicated hypertension or orthopedic problems and had no evidence of alcoholism, pancreatic disease or other medical illness discernible by history and medical chart review. All participants in the study were residents of Louisiana and had not traveled out- side the state during the past six months. They did not have any conditions known to predispose them to giardiasis, including homosexuality, cystic fibrosis or immunoglobulin deficiency syndromes (7-9).

Detection of $G$ lamblia was accomplished by collecting a single stool specimen and testing it by counterimmunoelectrophoresis (CIE) for the presence of $G$ lamblia surface antigens; these antigens are present on cysts and trophozoites (10). Ten microlitres of liquified stool was placed on the cathode end of an electrophoresis gel plate. The anode end contained rabbit immunoglobin ( $\mathrm{Ig}$ ) $\mathrm{G}$ and $\mathrm{IgM}$ from animals immunized with a purified preparation of $\mathrm{G}$ lamblia cysts. A constant potential $(220 \mathrm{~V})$ was applied for $30 \mathrm{mins}$, and the plates were examined for precipitation bands after 24 and 48 $\mathrm{h}$ of incubation at $4^{\circ} \mathrm{C}$. The presence of a precipitation band was considered diagnostic for $\mathrm{G}$ lamblia. Each stool specimen was tested twice. This CIE assay has been shown previously to be more sensitive than direct examination of stool and duodenal fluid, and has a sensitivity and specificity for detection of G lamblia greater than 95\% (10).

Statistical analysis of the results was made using the Fisher-exact test. $\mathrm{P}<0.05$ was considered statistically significant.

\section{RESULTS}

G lamblia was detected in four of 15 patients $(27 \%)$ with well-documented chronic pancreatitis (Table 1). None of the control subjects had evidence of giardiasis by CIE. The higher rate of giardiasis in the patients with chronic pancreatitis was statistically significant $(\mathrm{P}<0.001)$. The four patients who tested positive were among those who had evidence of weight loss, steatorrhea and postprandial abdominal pain (Table 1); these four had worsening symptoms which could not be control. led with increasing pancreatic enzyme supplementation, bicarbonate or histamine -2 receptor antagonists. The patients with positive results received a one-week course of antibiotic therapy for giardiasis (oral metronidazole 250 mg three times a day for seven days) without change in any other medication. Following treatment, they reported complete resolution of their diarrhea and abdominal pain, and CIE retesting of their stools revealed clearing of G lamblia.

\section{DISCUSSION}

In the current study, the prevalence of giardiasis in an adult population with alcohol-induced chronic pancreatitis was $27 \%$. Although the study group size was small, the prevalence rate is similar to the $28 \%$ for giardiasis found in larger groups of patients with cystic fibrosis, all of whom had pancreatic exocrine insufficiency (7). Combined consideration of the results from these two studies supports the hypothesis that pancreatic exocrine insufficiency may be a predisposing condition to intestinal colonization with $\mathrm{G}$ lamblia and suggests pancreatic exocrine secretion may have a role in host defense against $\mathrm{G}$ lamblia. The possible mechanisms by which pancreatic exocrine insufficiency may predispose patients to giardiasis include deficiency of pancreatic enzymes, decreased pancreatic bicarbonate secretion and absence of nonimmunological factors with antimicrobial activity normally present in pancreatic juice.

G lamblia, like some bacteria and other protozoa, has lectin activity associated with its surface membrane which has a high specificity for Dglycosyl and D-mannosyl residues (11, 12). This surface membrane lectin activity mediates giardia trophozoite adherence to intestinal epithelial cells with preference to those in the small intestine. Trypsin removes parasite surface lectin and possibly other surface determinants involved with parasite attachment to enterocytes, and may also mediate parasite release from the gut 
TABLE 1

Clinical data in 15 patients with chronic pancreatitis. First four patients had positive counterimmunoelectrophoresis for Giardia lamblia in their fecal samples

\begin{tabular}{|c|c|c|c|c|c|c|c|c|}
\hline Case & Age & Sex & $\begin{array}{l}\text { CP duration } \\
\text { since diag- } \\
\text { nosis (years) }\end{array}$ & $\begin{array}{c}\text { Diarrhea and } \\
\text { weight loss }\end{array}$ & $\begin{array}{l}\text { Pancreatic calcification } \\
\text { by plain abdominal } \\
\text { radiographs }\end{array}$ & $\begin{array}{c}\text { Abnormal } \\
\text { computed axial } \\
\text { tomography scan }\end{array}$ & $\begin{array}{c}\text { Abnormal } \\
\text { ERCP }^{\dagger}\end{array}$ & $\begin{array}{l}\text { Abnormal } \\
\text { secretin test } t^{\ddagger}\end{array}$ \\
\hline 1 & 36 & $M$ & 2 & + & - & & + & + \\
\hline 3 & 52 & $M$ & 3 & + & + & + & & + \\
\hline 4 & 65 & $M$ & 4 & + & + & + & & \\
\hline 5 & 33 & $M$ & 2 & + & - & & + & + \\
\hline 7 & 40 & $M$ & 8 & + & + & \pm & - & + \\
\hline 8 & 42 & $\mathrm{~F}$ & 3 & - & - & + & \pm & \\
\hline 9 & 47 & $M$ & 2 & - & - & + & & + \\
\hline 10 & 50 & $M$ & 5 & + & + & & & \\
\hline 11 & 53 & $\mathrm{~F}$ & 7 & + & - & + & & + \\
\hline
\end{tabular}

CPChronic pancreatitis; ERCPEndoscopic retrograde cholangiopancreatography: 'Enlargedpancreatic duct, calcificaiton and/or calculi; ${ }^{\dagger}$ Pancreatic duct dilation, irregularity, stricture and/or ductal calculi: ${ }^{7}$ Volume $<2 \mathrm{~mL} / \mathrm{kg} / \mathrm{h}$ and bicarbonate concentrations < $70 \mathrm{mEq} / \mathrm{L}$ after intravenous secretin (1 u/kg) stimulation

epithelium (11). In the absence or deficiency of tryptic activity, ability of $\mathrm{G}$ lamblia to attach to enterocytes may be enhanced.

G lamblia trophozoites can be killed in vitro by normal human duodenal and upper jejunal fluid. This effect has been attributed, in part, to products of lipolysis including unsaturated fatty acids, monoglycerides and lysophospholipids (13). In humans, lipid is digested by a number of lipases including pancreatic triacylglycerol lipase, carboxylester hydrolase and phospholipases A and B (14). The concentration of lipolytic products in intestinal fluid is dependent greatly on their relative rates of production which, in turn, directly is related to the secretion and availability of lipolytic enzymes and consumption of fat. In the absence of these enzymes, the lipolytic effect would be missing - thereby removing a potential defense against intestinal colonization by $\mathrm{G}$ lamblia.

The activity of pancreatic enzymes, both proteolytic and lipolytic, is $\mathrm{pH}$ sensitive. Whenever the duodenal $\mathrm{pH}$ falls below 4, these enzymes become irreversibly inactivated. In patients with chronic pancreatitis who have steatorrhea, bicarbonate secretion is reduced markedly, and there is impaired ability to neutralize even small loads of acid in the duodenum (15). Consequently, the intraluminal duodenal $\mathrm{pH}$ tends to be lower than 4 , rising to between 5 and 6 only during the early postprandial period (16). The abnormally low duodenal $\mathrm{pH}$ inactivates both lipolytic and proteolytic activity of pancreatic enzymes, thereby neutralizing the antimicrobial defence they normally would confer.

Within human pancreatic juice there is an antimicrobial factor which is $\mathrm{pH}$-dependent; its activity is optimal at $\mathrm{pH} 8.5$ but it is inactive when the $\mathrm{pH}$ drops to 7.0 or lower (17) and would, therefore, be active within the range of $\mathrm{pH}$ found in normal pancreatic secretions (18). The factor is heat stable, has been found to be bactericidal for enterobacteriaceae, bacteriostatic for Pneumocystitis aeruginosa and staphylococci, and fungistatic against Candida albicans (17). It is not an enzyme, immunoglobin or complement factor.

It is quite possible this factor (or other similar factors still unidentified in pancreatic juice) also are active against protozoa, including $\mathrm{G}$ lamblia. In patients with pancreatic exocrine insufficiency, one would expect both a deficiency of the factor(s) and complete loss of its activity in the duodenal lumen due to the lower $\mathrm{pH}$ of the intraluminal contents.

The authors' study reveals that it is important to investigate for $\mathrm{G}$ lamblia in any patient with pancreatic exocrine insufficiency whenever their symptoms are difficult to control by dietary and pancreatic enzyme measures. If left unrecognized, giardiasis superimposed on chronic pancreatic exocrine insufficiency may result in increased diarrhea and weight loss beyond that expected for the degree of pre-existing pancreatic disease.

ACKNOWLEDGEMENTS: This study was supported by Gastroenterology Research Fund $\# 625089$

\section{REFERENCES}

1. Knight R. Epidemiology and transmission of giardiasis. Trans R Soc Trop Med Hyg 1980;74:433-6.

2. Craun GF. Waterborne outbreaks of giardiasis in the United States, 1965-1984. Lancet 1986;ii:513-4.

3. Centers for Disease Control. Waterrelated disease outbreaks annual summary, 1982. 1983.

4. Chester AC, MacMurray FG, Restifo MD, Mann O. Giardiasis as chronic disease. Dig Dis Sci 1985;30:215-8. 
5. Brooks FP. Chronic and chronic relapsing pancreatitis. In: Brooks FP ed. Major Problems in Internal Medicine. Philadelphia; WB Saunders Co, 1980:40-4.

6. Sheehy TW, Holley HP. Giardiainduced malabsorption in pancreatitis. JAMA 1975;233:1373-5.

7. Roberts DM, Craft JC, Mather FJ, Davis SH, Wright JA. Prevalence of giardiasis in patients with cystic fibrosis. J Pediatr 1988;112:555-9.

8. Petersen H. Giardiasis (lambliasis). Scand J Gastroenterol 1972;7(Suppl 14):1-44.

9. Schmerin MJ, Jones TC, Klein H. Giardiasis-association with homosexuality. Ann Intern Med 1978;88:801-3.

10. Craft JC, Nelson JD. Diagnosis of giardiasis by counterimmunoelectrophoresis of feces. J Infect Dis 1982;145:499-504.

11. Inge PM, Edson CM, Farthing MJ. Attachment of Giardia lamblia to rat intestinal epithelial cells. Gut 1988;29:795-801.

12. Farthing MJ, Pereira ME, Keusch GT. Description and characterization of a surface lectin from Giardia lamblia. Infect Immunol 1986;51:661-7.

13. Das S, Reiner DS, Zenian J, et al. The killing of Giardia lamblia trophozoites by human intestinal fluid in vitro. J Infect Dis 1988;157:1257-60.

14. Jensen RG, Clark RM, dejong FA, Hamosh M, Liao TH, Mehta NR. The lipolytic triad - human lingual, breast milk, and pancreatic lipases physiological implications of their characteristics in digestion of dietary fats. J Pediatr Gastroenterol Nutr 1982;1:243-55

15. Dutta SK, Russell RM, Iber FL. Impaired acid neutralization in the duodenum in pancreatic insufficiency. Dig Dis Sci 1979;24:775-80.

16. DiMagno EP, Malagelada JR, Go VL, et al. Fate of orally ingested enzymes in pancreatic insufficiency-comparison of two dose schedules. N Engl J Med 1977;296:1318-22.

17. Rubenstein E, Mark Z, Haspel J, et al. Antibacterial activity of the pancreatic fluid. Gastroenterology 1985;88:927-32.

18. Caflisch CR, Solomon S, Galey WR. In situ micro-puncture study of pancreatic duct $\mathrm{pH}$. Am J Physiol 1980;238:G263-8. 


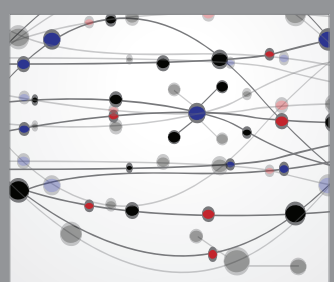

The Scientific World Journal
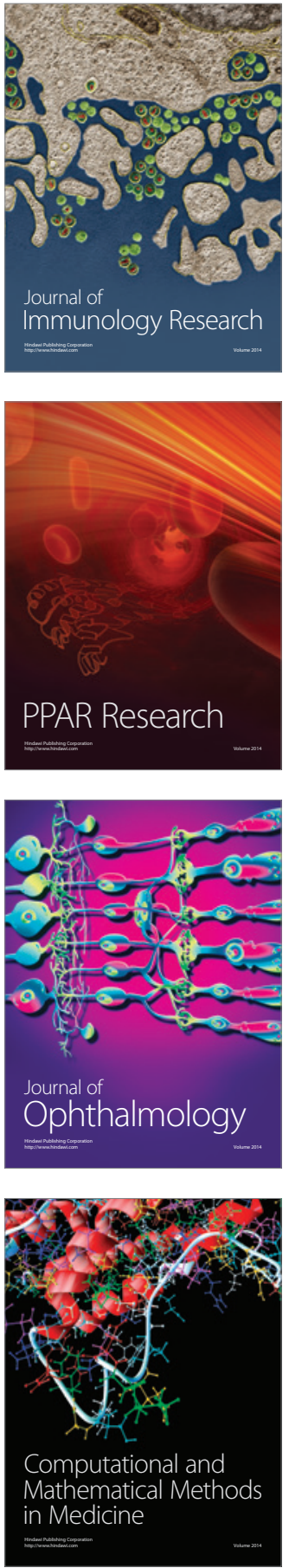

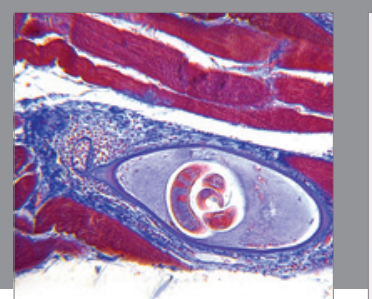

Gastroenterology Research and Practice

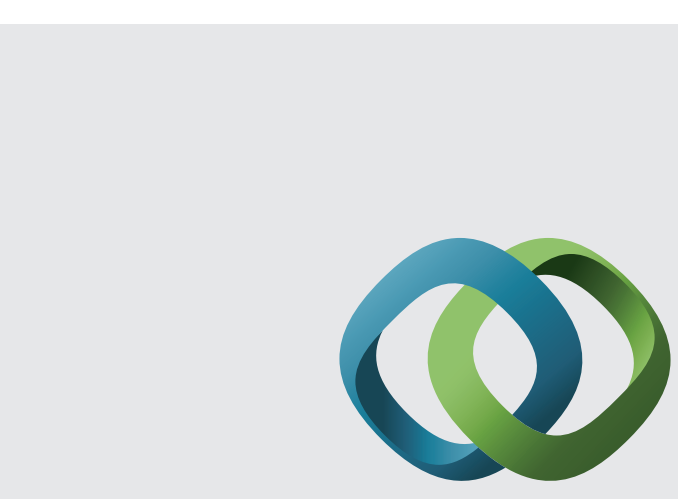

\section{Hindawi}

Submit your manuscripts at

http://www.hindawi.com
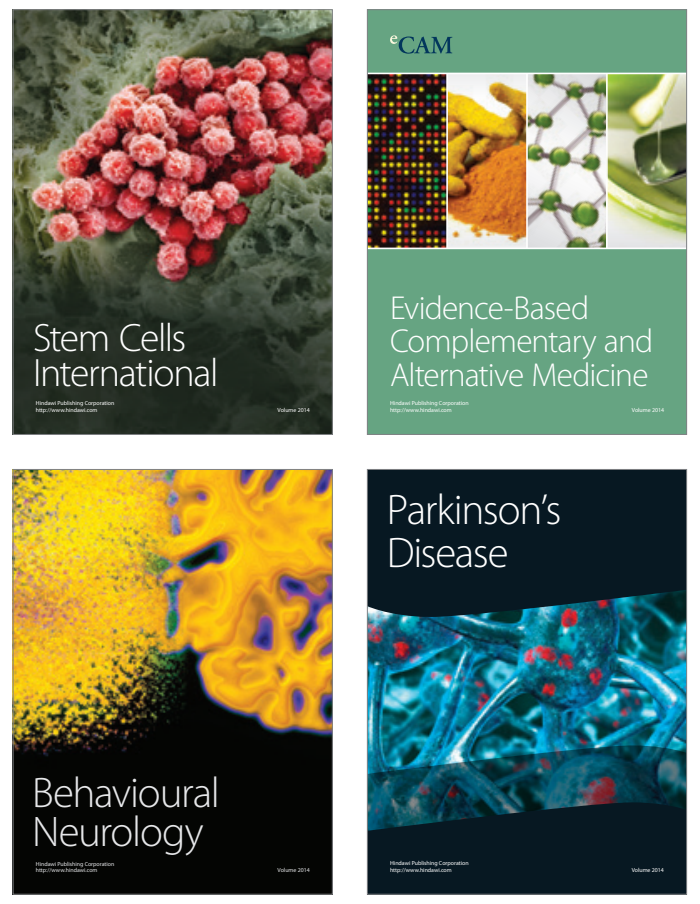
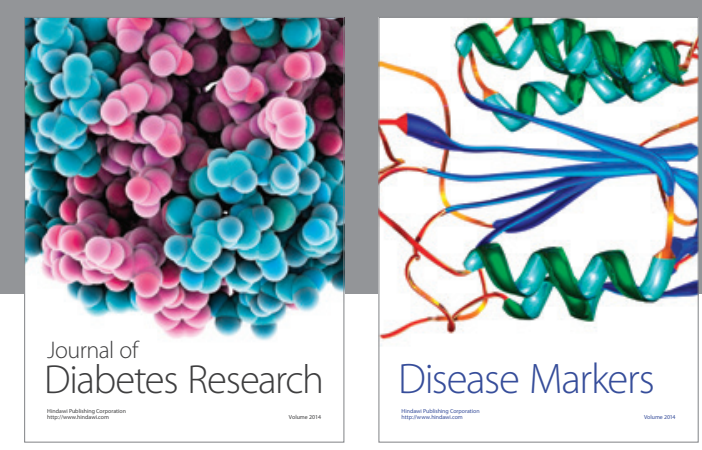

Disease Markers
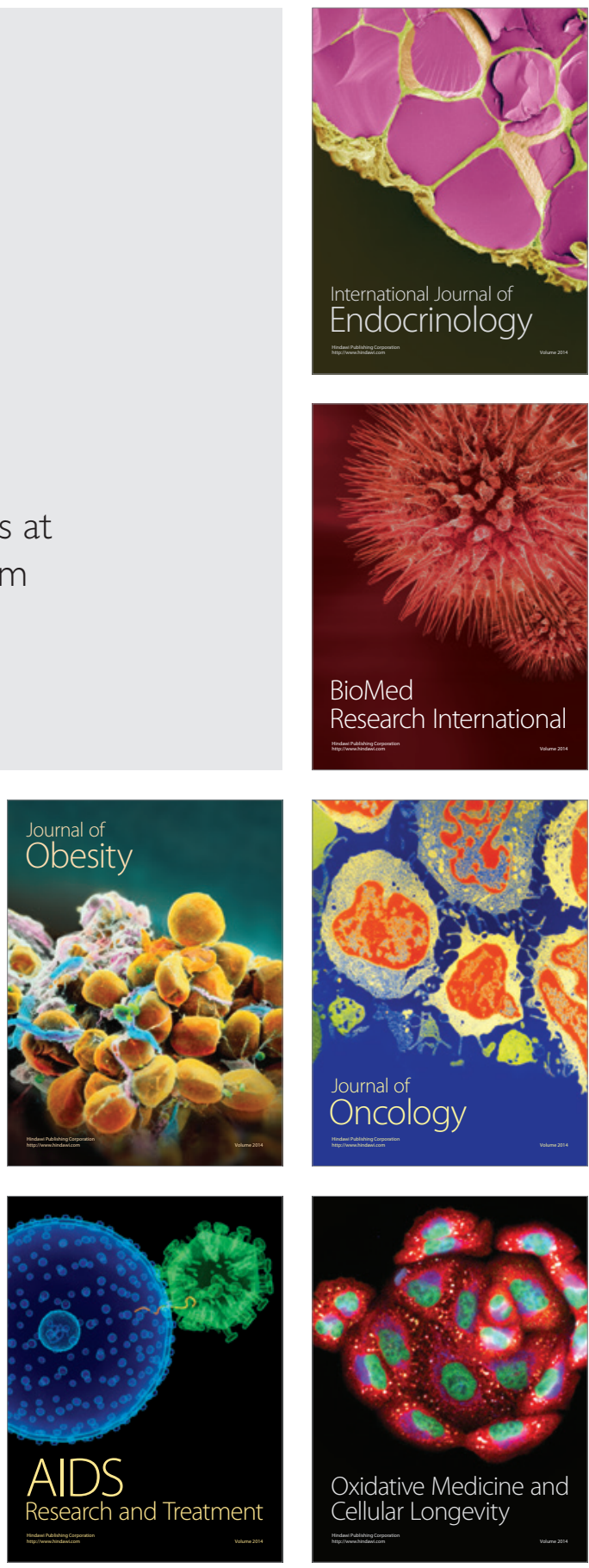